\title{
Studies on filariasis VIII: Histological observation on the abortive development of Brugia malayi larvae in the thoracic muscles of the mosquitoes, Armigeres subalbatus
}

\author{
Mutsuo Kobayashi, Nobuo Ogura and Hisashi Yamamoto \\ Department of Medical Zoology, Dokkyo University School of Medicine, \\ Tochigi 321-02, Japan
}

(Received: July 30, 1985)

\begin{abstract}
Key words: abortive development, filarial larvae, mosquito, Brugia malayi, Armigeres subalbatus.
\end{abstract}

\begin{abstract}
Abortive development of the filarial larvae, Brugia malayi, in the thorax of the refractory mosquito against the parasite was examined by a histological method. Until $24 \mathrm{hr}$ after infection G-cell of almost all of the larvae found in the thorax completed first cell division, however many of the larvae showed an abnormal appearance of cuticle. Until $48 \mathrm{hr}$ after infection almost all the larvae showed unusual features of cuticle and in some specimens prolapse of the cells were observed. On the 5th day after infection pigmentation around cuticle was observed on many larvae. Pigmentation which is blackish-brown in color remained unchanged in the thorax until the 10th day. The cellular response by the host mosquitoes, which was seen on the encapsulated larvae in the abdominal haemocoel, was not observed in the thoracic muscles.
\end{abstract}

\section{INTRODUCTION}

The filarial larvae which are taken by the refractory mosquitoes are hampered in successful migrations or further development at a various site of mosquito body. In regards with refractory species the presence of some barriers against the filarial larvae, such as pharyngeal and cibarial armatures in the foregut (Coluzzi and Trabucchi, 1968; McGreevy et al., 1978), peritrophic membrane in the midgut (Esslinger, 1962) and encapsulation in the abdominal haemocoel (Burton, 1963; Yamamoto et al., 1985) have been reported.

* 小林睦生, 小倉信夫, 山本 久: 獨協医科大学医 動物学教室（宁321-02 杤木県壬生町北小林 880)
There were the reports indicating that susceptibility of mosquito is genetically controlled by the gene such as $\mathrm{f}^{\mathrm{m}}$ to Brugia malayi and fi to Dirofilaria immitis (Macdonald, 1962a, b; Sulaiman and Townson, 1980).

Armigeres subalbatus has been shown to be refractory to $B$. malayi (Nakajima et al., 1976; Kobayashi et al., 1981). In the experimental infection of $B$. malayi to $A r$. subalbatus about $60 \%$ of the larvae were encapsulated in the abdominal haemocoel, about $20 \%$ remained in the midgut, and the rest $20 \%$ could migrate into the thoracic muscles by the time of $24 \mathrm{hr}$ after blood meal (Yamamoto et al., 1985).

Therefore, the encapsulation of the larvae in the abdominal haemocoel was assumed to be a main expression of the refractoriness 
of this species against $B$. malayi larvae.

However, it has been little studied what will take place with the larvae after their invasion into the thoracic muscles of the mosquitoes. The present study was focused to see how degenerative processes of the larvae in the thorax proceed by an ordinary histological method.

\section{Materials and Methods}

Armigeres subalbatus (406 strain) was used in the experiments. The history of this strain and the degree of susceptibility to Brugia malayi (periodic Che-ju strain, Korea) was described in the previous paper (Kobayashi et al., 1981). Mongolian jirds, Meriones unguiculatus, which were infected with $B$. malayi, were used as donors for infective meal. Two to five-day-old mosquitoes were fed on the jirds which had been previously anesthetized by intraperitoneal injection of pentobarbital sodium (Nembutal) at a dose of $2.5 \mathrm{mg} / 100 \mathrm{~g}$ of the body weight.

Fully engorged mosquitoes were fixed in $10 \%$ formalin solution at various time intervals of $0.5,3,12$, and $24 \mathrm{hr}$, on the 2nd, $3 \mathrm{rd}, 5$ th, 7 th and 10th day after blood meal. These specimens were embedded in paraffin (melting point $c a .56^{\circ} \mathrm{C}$ ) after an ordinary procedure and then sectioned serially at $10 \mu \mathrm{m}$ thickness. They were stained with hematoxylin and eosin.

Specimens thus sectioned from more than 90 infected mosquitoes were observed by a light microscope and photomicrographed using Panatomic-X film (Kodak).

\section{Results}

At $12 \mathrm{hr}$ after infection, there was no larvae in which G-cell had started the cell division, though some of them were noticeably shorter in size than microfilariae (Fig. 1). Any changes of cuticle or component cells of the larvae were not yet observed.

At $24 \mathrm{hr}$ after infection, G-cell of 20 out of 23 specimens had divided or in the process of division and some larvae showed normal development (Fig. 2). However, majority of the larvae showed an abnormal features of cuticle and pyknosis of many body cells (Fig. 3). There was one specimen showing some cells prolapsed through the broken cuticle (Fig. 4).

At $48 \mathrm{hr}$ after infection, almost all of the larvae showed an apparent abnormal features in both cuticle and cells of the larvae (Fig. 5). Prolapse of cells or clump of cells was seen in some specimens as a result of degeneration (Figs. 6 and 7). In other specimens vacuolation of the cells was observed all over the larval body (Fig. 8). Only in one sectioned specimen a normally developing larva was observed (Fig. 9).

At $72 \mathrm{hr}$ after infection, almost all the cells of the larvae became poor in staining and vacuolation was observed more frequently (Fig. 10). There was only one sectioned specimen around which partial encapsulation of a larva had started (Fig. 11). Therefore, it was suggested that the encapsulation could appear in the thoracic muscles only around the day 3 of the blood meal or later.

On the 5th day after infection, pigmentation around whole or partial cuticle was observed in almost all of the larvae (Figs. 12 and 13). Necrosis of the tissue of encapsulated larvae was more distinct (Fig. 14).

On the 7th day after infection, pigmentation by blackish-brown substance was more pronounced. There was one specimen in which one larva was found to reach a late first stage of development. However this larva also showed some unusual morphology already (Fig. 15).

On the 10th day after infection, almost all of the larvae were strongly pigmented and did not develop beyond the middle first stage. In the most of the 10 th day specimens the encapsulated larvae were observed like a ghost of blackish-brown envelope (Fig. 16).

\section{Discussion}

It is known that larval development in the thoracic muscles of the susceptible mosquito species is initiated by the division of G-cell (Schacher, 1962; Laurence and Simpson, 1971). This first mitosis occurs from 18 to $24 \mathrm{hr}$ after blood meal and is followed by daughter G-cell division to form 4 cells at about 28 to $30 \mathrm{hr}$. In a refractory Aedes 


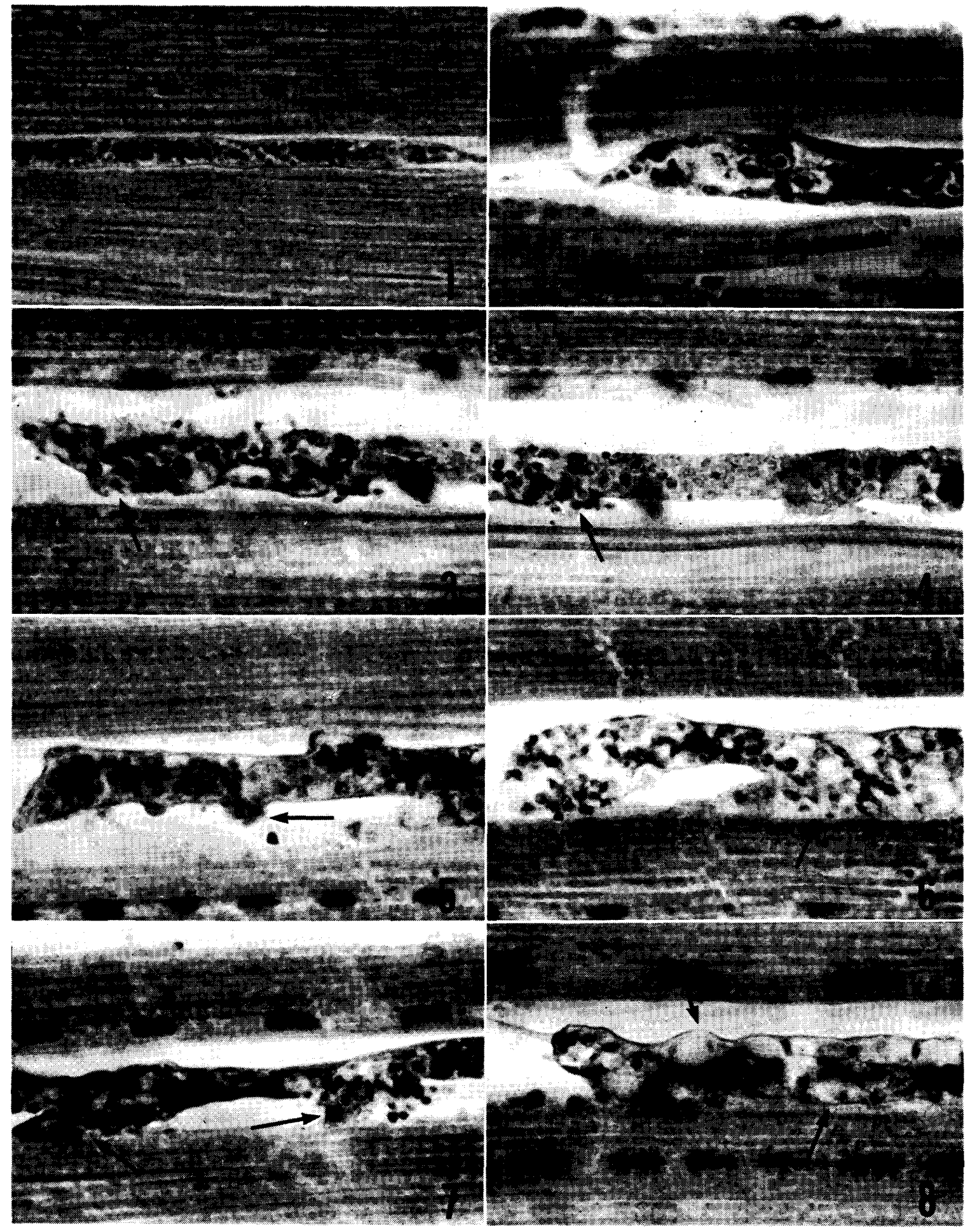

Fig. 1 Twelve hr post-infection, apparently normally developing larva is shown. Fig. 2 Twenty-four hr post-infection, normally developing larva. Fig. 3 Twenty-four hr postinfection, discontinuity of cuticle and pycnosis of cells is shown (arrow). Fig. 4 Twenty-four hr post-infection, prolapse of cells (arrow). Fig. 5 Forty-eight hr post-infection, discontinuity of cuticle and prolapse of cells (arrow). Figs. 6 and 7 Forty-eight hr post-infection, marked prolapse of cells (arrow) from degenerating larva. Fig. 8 Forty-eight hr postinfection, vacuolation (arrow) of degenerating larva. 


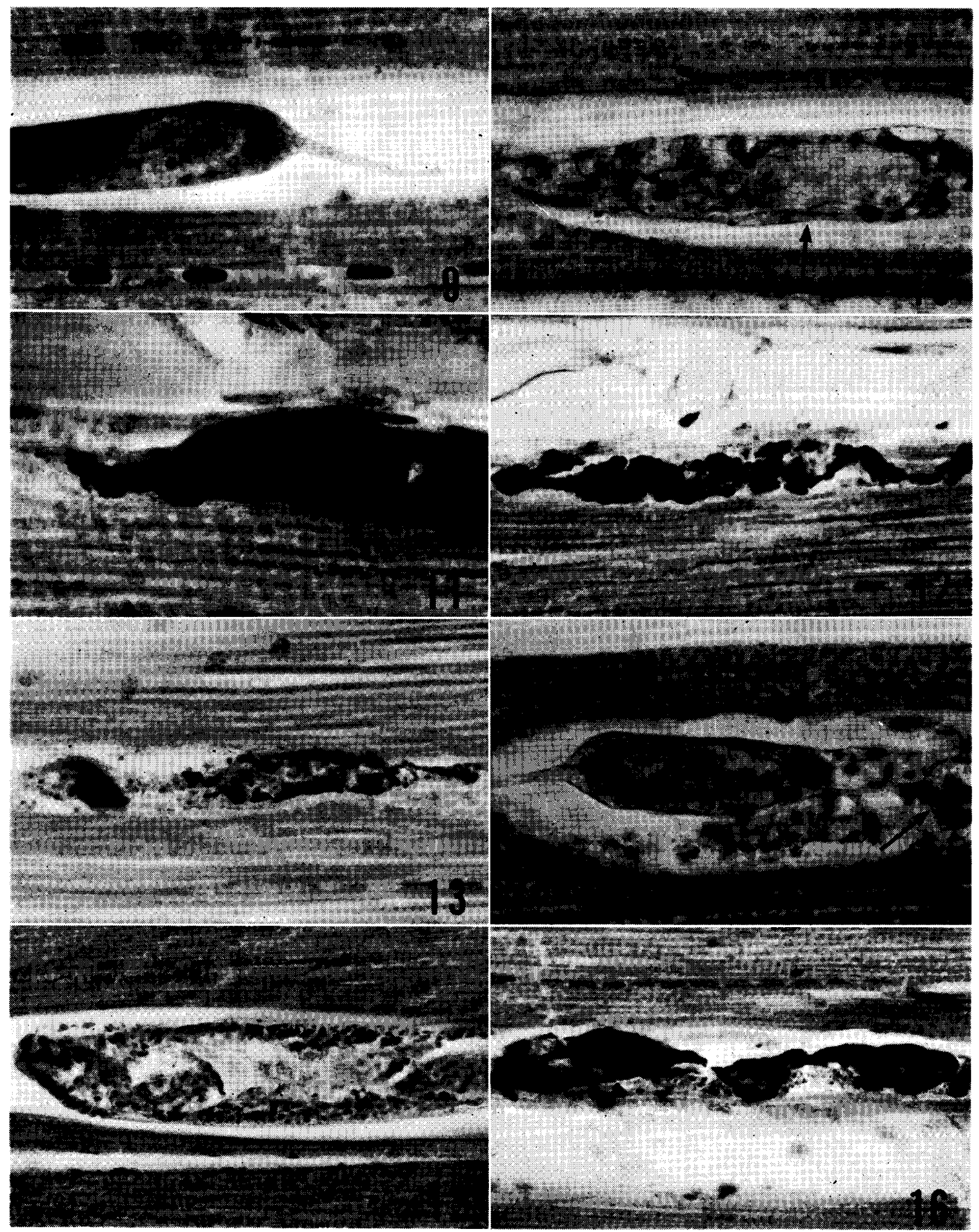

Fig. 9 Forty-eight hr post-infection, normally developing larva, showing rectum cells (black arrowhead). Fig. 10 Seventy-two hr post-infection, marked vacuolation (arrow) and indistinct nuclei of cells is shown. Fig. 11 Seventy-two hr post-infection, pigmentation (encapsulation) is recognized at the posterior region of larva. Fig. 12 Five days postinfection, completely encapsulated larva. Fig. 13 Five days post-infection, partially encapsulated larva. Fig. 14 Five days post-infection, degenerating larva with partial pigmentation (arrow), showing more marked vacuolation all over the larval body. Fig. 15 Seven days post-infection, larva developing beyond the middle 1st stage, showing abnormal cell arrangement. Fig. 16 Ten days post-infection, completely encapsulated larva; pigmented capsule is observed like an exoskelton. 
aegypti G-cell of $B$. patei may not divide at all and in Anopheles labranchiae atroparvus, also refractory one, G-cell may divide but the formation of intestine is completely inhibited (Laurence and Simpson, 1971). In Culex pipiens fatigans, a moderately susceptible mosquito to Wuchereria bancrofti, G-cell division is delayed and takes place at 36 to $62 \mathrm{hr}$ post-infection, despite that larval development has started before the first G-cell division (Omar and Zielke, 1978).

The present observation showed that the first G-cell division in the majority of the specimens examined had completed by $24 \mathrm{hr}$ after infection and that almost all of the larvae in the $24 \mathrm{hr}$ specimens had been partially degenerated. Therefore, it is suggested that G-cell division would not be a necessary criterion of further successful development of the filarial larvae.

Degeneration of the larvae started very early and almost all of the larvae were observed degenerated by $48 \mathrm{hr}$ after infection, and pigmentation was first observed in a specimen of $72 \mathrm{hr}$ after infection. It is clear that pigmentation around the larvae in the muscles takes place as a result of degeneration of the larvae.

It has been shown that $B$. malayi larvae are first encapsulated in the abdominal haemocoel of $A r$. subalbatus even if they are actively motile and then haemocyte-like cells attach on the capsule as early as $3 \mathrm{hr}$ postinfection (Kobayashi et al., 1986).

In contrast, degeneration of the larvae was observed first and then pigmentation of the larvae followed in the thorax. Host cell involvement was not observed around pigmented larvae in the thoracic muscles. It is likely that host cells are not capable to migrate easily into the muscles.

As a result, it is concluded that the host responses in the thorax, as observed in combination of $B$. malayi and $A r$. subalbatus, might be governed by different mechanisms from the ones in the abdominal haemocoel.

\section{AGKNOWLedGements}

The authors are indebted to Miss M. Okazaki and Miss T. Minowa in the department for their collaboration.

\section{RefERENGES}

Burton, G. J. (1963) : Encapsulation of Wuchereria bancrofti in seven species of mosquitoes in British Guyana. Am. J. Trop. Med. Hyg., 12: $870-876$.

Coluzzi, M. and R. Trabucchi (1968): Importanza dell'armatura bucco-faringea in Anopheles e Culex in relazione alle infezioni con Dirofilaria. Parasitologia, 10: 47-59.

Esslinger, J. H. (1962): Behavior of microfilariae of Brugia pahangi in Anopheles quadrimaculatus. Am. J. Trop. Med. Hyg., 11: 749-758.

Kobayashi, M., N. Ogura and H. Yamamoto (1981): Studies on filariasis III : Susceptibility of several mosquito species to periodic Che-ju (Korea) strain of Brugia malayi. Jpn. J. Sanit. Zool., 32: 293-299.

Kobayashi, M., N. Ogura, H. Tsuruoka, Y. Chigusa and S. Mishima (1936): Studies on filariasis VII: Histological observation on the encapsulated Brugia malayi larvae in the abdominal haemocoel of the mosquitoes, Armigeres subalbatus. Jpn. J. Sanit. Zool., 37: 59-65.

Laurence, B. R. and M. G. Simpson (1971) : The microfilaria of Brugia: A first stage nematode larva. J. Helminth., 45: 23-40.

Macdonald, W. W. (1962a): The selection of a strain of Aedes aegypti susceptible to infection with semi-periodic Brugia malayi. Ann. Trop. Med. Parasitol., 56: 368-372.

Macdonald, W. W. (1962b): The genetic basis of susceptibility to infection with semi-periodic Brugia malayi in Aedes aegypti. Ann. Trop. Med. Parasitol., 56: 373-382.

McGreevy, P. B., J. H. Bryan, P. Oothuman and N. Kolstrup (1978): The lethal effects of the cibarial and pharyngeal armatures of mosquitoes on microfilariae. Trans. R. Soc. Trop. Med. Hyg., 72: 361-368.

Nakajima, Y., Y. Aoki, M. Sakamoto, O. Suenaga and D. Katamine (1976): Studies on Malayan filariasis in Che-ju Island, Korea 4. Experimental transmission of Brugia malayi (Che-ju strain) to domesic cats. Jpn. J. Trop. Med. Hy'g., 4: 163-177.

Omar, M. S. and E. Zielke (1978): Abortive development of Wuchereria bancrofti in a west african strain of Culex pipiens fatigans. Tropenmed. Parasitol., 29: 364-370.

Schacher, J. F. (1962): Morphology of the microfilaria of Brugia pahangi and of the larval stages in the mosquito. J. Parasitol., 48: 679692.

Sulaiman, I. and H. Townson (1980): The genetic basis of susceptibility to infection with 
Dirofilaria immitis in Aedes aegypti. Ann. Trop. Med. Parasitol., 74: 635-646.

Yamamoto, H., M. Kobayashi, N. Ogura, H. Tsuruoka and Y. Chigusa (1985): Studies on filariasis VI: The encapsulation of Brugia malayi and $B$. pahangi larvae in the mosquito, Armigeres subalbatus. Jpn. J. Sanit. Zool., 36: 1-6.

\section{摘 要}

杀状虫症に関するる研究

VIII：オオクロヤブカ胸部筋肉内における マレー糸状虫幼虫の発育に関する組織学的観察

マレ一糸状虫に非感受性である蚊の，胸部での糸状
虫幼虫の発育を組織学的に観察した。感染後24時間ま でに胸部に移行した大部分の幼虫では $\mathrm{G}$ 細胞の分裂が すでに始まっていたが，それらの幼虫の多くは角皮層 に形態的異常を示していた. 感染後48時間においては ほぼすべての幼虫に角皮層の異常が認められ，一部の 標本では幼虫構成細胞の脱出が観察された. 感染後 5 日の標本では多くの幼虫においいて角皮層の周囲に色素 沈着が観察された.この黒褐色を呈する色素沈着は, 感染後10日の標本においても変化せずに，5日目以降 の標本と同様に認められた。

一方前報で明らかにされたオオクロヤブカ腹部体腔 内での被顀化幼虫への宿主細胞の付着は，胸筋内では まったく認められなかった。 